\title{
Vitamin D status in North Greenland is influenced by diet and season: indicators of dermal 25-hydroxy vitamin D production north of the Arctic Circle
}

\author{
Stig Andersen ${ }^{1,2,3 *}$, Anna Jakobsen ${ }^{1}$ and Peter Laurberg ${ }^{1,4}$ \\ ${ }^{1}$ Arctic Health Research Centre, Aalborg University Hospital, Hobrovej 42D-1, 9000 Aalborg, Denmark \\ ${ }^{2}$ Department of Internal Medicine, Queen Ingrids Hospital, Nuuk, Greenland \\ ${ }^{3}$ Department of Geriatrics and Medicine, Aalborg University Hospital, Aalborg, Denmark \\ ${ }^{4}$ Department of Endocrinology, Aalborg University Hospital, Aalborg, Denmark
}

(Submitted 2 March 2012 - Final revision received 17 September 2012 - Accepted 17 September 2012 - First published online 27 November 2012)

\section{Abstract}

Vitamin D status, as measured by serum 25-hydroxy vitamin D (s-25OHD), is important to human health. Dermal 25OHD production depends on UVB light that is influenced by latitude. We aimed to identify factors important to the production of s-25OHD in Arctic people and investigated subjects living in the town of Ilulissat and the settlement of Saqqaq in North Greenland ( $70^{\circ} \mathrm{N}$ ) during the four seasons. Participants were enrolled with a balanced representation of non-Inuit and Inuit in Ilulissat and Inuit in Saqqaq, men and women, aged 30-39 and 40-49 years. Supplement use, hours spent outdoors and other lifestyle factors were determined by questionnaires. Scores of traditional Inuit food intake were computed from a FFQ at inclusion, and frequencies of intake were recorded at each visit. s-25OHD concentration was measured. There were sixty-four Inuit and thirty-three non-Inuit participants. Inuit food score $<40 \%$ was found in 87, 64 and $48 \%$ of non-Inuit, Inuit in Ilulissat and Inuit in Saqqaq participants, respectively $(P=0 \cdot 009)$. Inuit diet associated positively with s-25OHD $(P<0 \cdot 001)$. s-25OHD concentration was lower in non-Inuit than in Inuit participants (spring/summer/autumn/

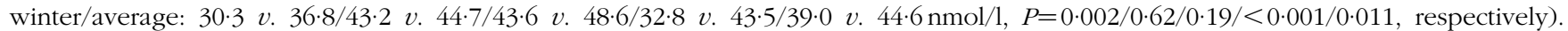
s-25OHD levels differed with season (Inuit, $P<0.001$; non-Inuit, $P<0.001$ ) as did diet (Inuit, $P<0.001$; non-Inuit, $P<0.001$ ) and hours spent outdoors (Inuit, $P<0.001$; non-Inuit, $P=0 \cdot 012)$. s-25OHD level was influenced by diet $(P<0 \cdot 001)$, season $(P<0 \cdot 001)$, origin $(P=0.001)$, residence $(P=0.013)$ and sex $(P=0.026)$. We conclude that the season influenced vitamin $\mathrm{D}$ status in Arctic populations beyond diet, ethnicity and vitamin intake. This suggests dermal $25 \mathrm{OHD}$ production at a high latitude of $70^{\circ} \mathrm{N}$.

\section{Key words: Vitamin D: Season: Diet: FFQ: Arctic North Greenland: Dermal production: Inuit Eskimos}

Vitamin D is important to human health. Vitamin D deficiency is associated with an increase in the risk of osteoporosis, falls and fractures ${ }^{(1-3)}$, and epidemiological evidence has linked poor vitamin D status to a number of inflammatory, infectious, cardiovascular and metabolic disorders and with cancers ${ }^{(1,4,5)}$.

The endogenous production of vitamin $\mathrm{D}$ in man depends on UVB-mediated conversion of 7-dehydrocholesterol to pre-vitamin $D_{3}$ and further isomerisation to vitamin $D_{3}$ (25OHD) in the skin ${ }^{(4)}$. This depends on exposure to sunlight, and serum 25OHD levels decrease with increasing latitude and vary with season ${ }^{(1,4,5)}$.

Populations living above the Arctic Circle are characterised by no sun exposure at about mid-winter. Also, a high solar zenith angle during summer suggests a limited sun exposure during this supposedly compensatory season. This is further added to by the need for protective outdoor clothing even during the Arctic summer, defined by a mean mid-summer temperature below $10^{\circ} \mathrm{C}$. Thus, very limited dermal 25OHD production is expected in Arctic residents.

The intensity of the light at sun appearance in spring is extremely high due to reflections from snow and ice. Thus, suntan and cataract are common among people with an outdoor occupation, and sun block and sunglasses are necessary in Greenland from early spring. Whether this contributes to some dermal 25OHD production remains to be settled.

The traditional Inuit diet consists mainly of sea mammals and free-living fish ${ }^{(5-8)}$. These food items are particularly rich in vitamin $\mathrm{D}^{(5)}$ and may be an important source of $25 \mathrm{OHD}$. However, the traditional Inuit diet varies with season ${ }^{(6,7)}$ and this

Abbreviation: 25OHD, 25-hydroxy vitamin D.

*Corresponding author: Dr S. Andersen, fax +45 99326108, email stiga@dadlnet.dk 
may contribute to seasonal differences in serum 25OHD concentration.

This led us to study the influence of dietary habits and season on the levels of $25 \mathrm{OHD}$ in serum in population cohorts living $400 \mathrm{~km}$ above the Arctic Circle in North Greenland, with 1 month of darkness at mid-winter and 1 month of $24 \mathrm{~h}$ sun at mid-summer.

\section{Subjects and methods}

\section{Area of investigation}

Ilulissat $\left(69^{\circ} 22^{\prime} \mathrm{N}\right)$ and Saqqaq $\left(70^{\circ} 05^{\prime} \mathrm{N}\right)$ are situated in North Greenland, 400 and $500 \mathrm{~km}$ north of the Arctic Circle, respectively (Fig. 1), by the UNESCO Heritage Ilulissat Icefjord. Sun does not set from 21 May to 24 July and the polar night extends from 1 December to 13 January. Ilulissat has 4500 inhabitants, of whom approximately $90 \%$ are Inuit (Eskimo) and 10\% non-Inuit (Caucasian Danes) populations. Ilulissat can be accessed by sea 7 months a year and has a variety of imported food items available in two major stores, supplementary to the traditional Greenlandic food items. Saqqaq is a settlement with 180 inhabitants and has one store with some market foods available, depending on access by sea and air.

\section{Subjects and procedures}

Procedures and subjects participating in January have been described previously ${ }^{(9)}$. Names and addresses were obtained from the National Civil Registration System, in which every person living in Denmark, the Faeroe Islands and Greenland is recorded. A random sample was drawn and participants in Ilulissat were stratified by age, sex and place of birth (Greenland or Denmark), aiming at a balanced representation of the age groups 30-39 and 40-49 years, men and women and the three groups consisting of subjects born in Greenland and living in the town, living in the settlement and subjects

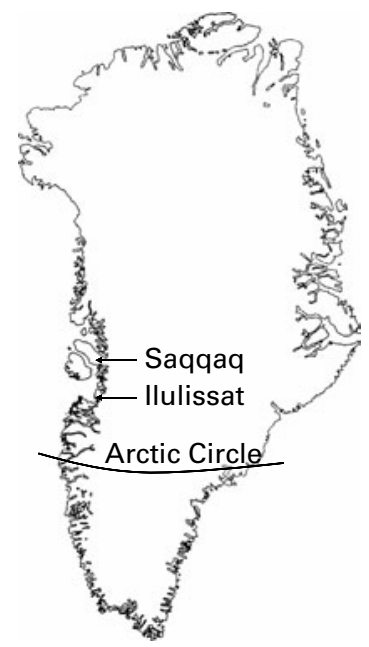

Fig. 1. Map of Greenland that depicts the town of Ilulissat $\left(69^{\circ} 22^{\prime} \mathrm{N}\right)$ and the settlement of Saqqaq $\left(70^{\circ} 05^{\prime} \mathrm{N}\right) 400$ and $500 \mathrm{~km}$ north of the Arctic Circle, respectively. Ilulissat has slightly more than 1 month of polar night and 1 month of midnight sun. who were not born in Greenland. This age range was chosen to ensure sufficient numbers of non-Inuit participants, as they are skilled labourers from Denmark who work in Greenland while in this age range. None of the participants had disease affecting bone, vitamin D absorption or vitamin D metabolism. Participants in Saqqaq (all Inuit) were matched to the Inuit participants in Ilulissat by age and sex. Data in Ilulissat were collected in spring (30 March through to 10 April 2001), summer (25 June through to 5 July 2001), autumn (25 September through to 5 October 2001) and winter (7 January through to 19 January 2002). Participants in Saqqaq were enrolled during summer 2001 and spring data were collected from 25 March through to 29 March 2002. In all, ninety-seven healthy subjects participated. A Greenlander (Inuit) was defined as an individual born in Greenland, with both parents born in Greenland.

A letter of invitation was delivered by the local hospital porter or the nursing station attendant. The investigation took place at Ilulissat hospital or at the nursing station in Saqqaq or, at request, at home visits. A physical examination was performed that included height without shoes, weight in indoor clothing and recording of major disabilities. Participants were interviewed by a Greenlandic interpreter or by one of the investigational doctors completing a questionnaire in either Greenlandic or Danish, as appropriate for the participant. Information regarding age and sex was obtained from the National Civil Registration System. Information on smoking habits (present/ past/never), alcohol intake (units/week), hunting (none, leisure or trade), number of hours outdoors as an average of yesterday, daily the latest week and daily over the last month, the use of vitamin preparations each season (daily/ occasional/never) and dietary habits was obtained by questionnaires. Questions were asked as written in the questionnaires.

A non-fasting blood sample was drawn from the cubital vein using minimal tourniquet. Serum was separated and kept at $-20^{\circ} \mathrm{C}$ until analysis.

Ethical approval by the Commission for Scientific Research in Greenland was obtained (505-63), and all subjects gave informed written consent in Danish or Greenlandic by participant choice.

\section{Dietary habits}

An interview-based FFQ was used to assess dietary habits. The questionnaire used at inclusion has been described in detail previously, and it has been validated using urinary iodine excretion as a biomarker for the intake of traditional Inuit food items ${ }^{(7)}$. Fish and blubber from marine mammals that are rich in dietary iodine and vitamin D dominate these food items. The questionnaire asked the frequency of intake of seven traditional Inuit food items (seal, whale, wild fowl, fish, reindeer, musk ox and hare) and seven imported food items (pre-cooked meals, potatoes, vegetables, butter, cheese, eggs and fresh fruit). Six different frequency categories were given for each food item. These were daily intake, four to six times weekly, one to three times weekly, two to three times monthly, once a month or less and never. A frequency score was calculated based on the average number of days per 
month that each individual food item was ingested ${ }^{(7)}$. Inuit food items scored positively and imported food items scored negatively. The sum of frequency scores for all food items consumed by each individual participant was calculated and the individual participants were categorised by quintiles of scores: diet group 1: $>80 \%$; 2: 60-80\%; 3: 40-60\%; 4: 20-40\%; and 5: $<20 \%$ Inuit food item scores on a scale, where $100 \%$ was pure Inuit foods and $0 \%$ was pure imported food. As a further check on adherence to the traditional Inuit diet, participants were asked the number of days per week that their main meal consisted of traditional Inuit food items. This was reported for each of the four seasons at inclusion and, in addition, it was asked during each data collection.

The intake of vitamin D-containing supplements was evaluated by asking the frequency of intake at each of the four seasonal data collections. Supplements were presented to one of the investigational doctors for evaluation of vitamin D content. Vitamin D-fortified foods are not available in Greenland.

\section{Vitamin D assay}

Plasma 25OHD levels were measured by a liquid-phase RIA (Gamma-B 25-Hydroxy Vitamin D RIA; Immunodiagnostic Systems Limited) that has an intra-assay precision of $5.3 \%$ at $26 \mathrm{nmol} / 1,5 \cdot 0 \%$ at $58 \mathrm{nmol} / 1$ and $6 \cdot 1 \%$ at $151 \mathrm{nmol} / 1$, and an inter-assay precision of $8.2 \%$ at $20 \mathrm{nmol} / 1,8.1 \%$ at $57 \mathrm{nmol} / 1$ and $7 \cdot 3 \%$ at $136 \mathrm{nmol} / 1$ (information provided by the supplier).

\section{Statistics}

Results are given as frequencies, means and medians with quartiles. Unrelated samples were compared using the Mann-Whitney $U$ test for two groups and the KruskalWallis test for more than two groups. Kendall's $\tau$ tested for trend. Related samples were compared using Friedman's test, i.e. between the four seasons. A season ratio of serum vitamin $\mathrm{D}$ was calculated by dividing the autumn by spring values for each participant. Explanatory variables entered in multivariate logistic regression analysis were season, diet, origin, age, sex, use of supplements, residence and weight. The dependent variable was serum 25OHD, with levels above/below $50 \mathrm{nmol} / \mathrm{l}$. Data were processed and analysed using Corel Quattro Pro 8 (Corel Corporation) and the Statistical Package for the Social Sciences version 13.0 (SPSS, Inc.). A $P$ value of less than 0.05 was considered significant.

\section{Results}

Of the ninety-seven participants enrolled, seventy participated in all four seasons, fifteen in three seasons, nine in two seasons and three participated just once. The reason for non-participation was hunting in all but one individual, who moved to Denmark. The characteristics of all ninety-seven participants enrolled are presented in Table 1. Age and sex did not differ between Inuit and non-Inuit participants, according to inclusion. Non-Inuit participants were the more frequent users of vitamin D-containing preparations, though daily use was low in both groups. Alcohol intake differed, as more Inuit participants were abstainers. Hunting was the main trade among Inuit men in the settlement and still frequent among Inuit men in the town. It did not differ between Saqqaq and Ilulissat ( 36 v. $25 \% ; P=0.52$, data not shown).

Inuit food frequency score groups are shown in Table 1. Scores differed markedly between Inuit and non-Inuit participants $(P=0.022)$, between non-Inuit, Inuit in town and Inuit in settlement participants $(P=0.029)$ and with place of living in Inuit $(P=0.023)$ (data not shown). Also, main meal of traditional Inuit food items was more frequent in Inuit than in non-Inuit participants (Table 1), and more frequent among Inuit participants in settlement compared with Inuit participants in town (4-7 d/week in Saqqaq v. Ilulissat, 64 v. 29\%, $P=0.026$ ) (data not shown). Days with main meal of Inuit food items were associated with food frequency scores (Kendall's $\tau$ 0.34, $P=0 \cdot 001$ ).

Average serum $25 \mathrm{OHD}$ levels below $50 \mathrm{nmol} / \mathrm{l}$ in individual participants was common (Table 1), but decreased with increasing intake of Inuit foods $(P=0.023)$ and differed between Inuit and non-Inuit $(P=0.001)$ participants. None had average serum 25OHD levels below $20 \mathrm{nmol} / 1$. Serum $25 \mathrm{OHD}$ levels below $50 \mathrm{nmol} / \mathrm{l}$ was more common following the polar night than following the spring and summer with midnight sun $(P=0.003$, Table 1$)$.

Table 2 lists average and seasonal serum 25OHD concentrations for each participant group in the sixty-three participants who attended the investigation in all four seasons and who did not take vitamin D-containing supplements. Serum 25OHD levels differed markedly with season in all groups. Overall, a rise in serum 25OHD levels was seen in spring and continued during summer, and the concentration was $28 \%$ higher in autumn than in spring, as illustrated by the autumn:spring ratio. Sex differences in serum 25OHD levels were marked in Inuit $(P=0 \cdot 013)$ but not in non-Inuit participants $(P=0.88)$. Serum 25OHD level was higher in Inuit than in non-Inuit participants $(P=0.011)$, and differed in Inuit $v$. non-Inuit men $(P=0.001)$ but not in women $(P=0.74)$. It was higher in the older age group $(P=0.023)$. Serum 25OHD levels increased gradually with increasing Inuit food frequency scores $(P=0.003)$ (data not shown) and it rose with the number of days that the main meal was prepared from local foods (Table $2, P=0 \cdot 019$ ). The group with the lowest quintile of Inuit food frequency scores had a serum 25OHD concentration of $36 \mathrm{nmol} / 1$, while it was $68 \mathrm{nmol} / 1$ in those having the highest quintile of Inuit food intake (data not shown). Seasonal differences tended to decrease with more frequent intake of Inuit food $(P=0.055)$. Still, a $14 \%$ seasonal difference in serum 25OHD levels was seen in the group with the highest intake of Inuit foods (Table 2).

The intakes of traditional Inuit foods reported by participants at each of the seasonal visits are depicted in Fig. 2. Differences in Inuit food frequencies between the four seasons were limited but statistically significant (non-Inuit, $P<0.001$; Inuit in town, $P<0.001$; and Inuit in settlement, $P<0.001)$. When asked about food intake during all four seasons at the time of the inclusion visit, no differences in terms of traditional food 
Table 1. Characteristics of participants in the survey performed in North Greenland $400 \mathrm{~km}$ above the Arctic Circle (Number of participants and percentages)

\begin{tabular}{|c|c|c|c|c|c|c|c|}
\hline & \multicolumn{2}{|c|}{ All } & \multicolumn{2}{|c|}{ Inuit } & \multicolumn{2}{|c|}{ Non-Inuit } & \multirow[b]{2}{*}{$P^{*}$} \\
\hline & $n$ & $\%$ & $n$ & $\%$ & $n$ & $\%$ & \\
\hline All participants & 97 & 100 & 64 & 100 & 33 & 100 & \\
\hline \multicolumn{8}{|l|}{ Residence } \\
\hline Town & 72 & 74 & 39 & 61 & 33 & 100 & \\
\hline Settlement & 25 & 26 & 25 & 39 & 0 & 0 & \\
\hline Sex & & & & & & & 0.47 \\
\hline Men & 48 & 49 & 30 & 45 & 18 & 53 & \\
\hline Women & 49 & 51 & 34 & 55 & 15 & 47 & \\
\hline Age group (years) & & & & & & & 0.32 \\
\hline $30-39$ & 55 & 57 & 34 & 53 & 21 & 64 & \\
\hline $40-49$ & 42 & 43 & 30 & 47 & 12 & 36 & \\
\hline Vitamins† & & & & & & & 0.019 \\
\hline Daily & 7 & $7 \cdot 2$ & 4 & $6 \cdot 3$ & 3 & $9 \cdot 1$ & \\
\hline Occasional & 57 & 59 & 32 & 50 & 25 & 76 & \\
\hline Never & 33 & 34 & 28 & 44 & 5 & 15 & \\
\hline Smokerł & & & & & & & 0.05 \\
\hline Present & 50 & 53 & 38 & 60 & 12 & 37 & \\
\hline Past & 15 & 16 & 10 & 16 & 5 & 16 & \\
\hline Never & 30 & 31 & 15 & 24 & 15 & 47 & \\
\hline Alcohol intake (units/week)§ & & & & & & & 0.002 \\
\hline None & 17 & 18 & 16 & 26 & 1 & 3 & \\
\hline $1-14$ & 68 & 72 & 38 & 61 & 30 & 85 & \\
\hline $15+$ & 9 & 10 & 8 & 13 & 4 & 12 & \\
\hline Hunter\| & & & & & & & $<0.001$ \\
\hline Trade & 13 & 15 & 13 & 21 & 0 & 0.0 & \\
\hline Inuit food frequency score (\%) & & & & & & & $<0.001$ \\
\hline$<20$ & 5 & $5 \cdot 6$ & 4 & $6 \cdot 9$ & 1 & $3 \cdot 1$ & \\
\hline $20-40$ & 57 & $63 \cdot 3$ & 30 & $51 \cdot 7$ & 27 & 84.4 & \\
\hline $40-60$ & 27 & $30 \cdot 0$ & 23 & $39 \cdot 7$ & 4 & $12 \cdot 5$ & \\
\hline$>60$ & 1 & $1 \cdot 1$ & 1 & $1 \cdot 7$ & 0 & 0.0 & \\
\hline Main meal Greenlandic (d/week) & & & & & & & $<0.001$ \\
\hline $0-1$ & 32 & $33 \cdot 0$ & 8 & $12 \cdot 5$ & 24 & $72 \cdot 7$ & \\
\hline $2-3$ & 39 & $40 \cdot 2$ & 30 & $46 \cdot 9$ & 9 & $27 \cdot 3$ & \\
\hline $4-7$ & 26 & $26 \cdot 8$ & 26 & $40 \cdot 6$ & 0 & 0.0 & \\
\hline Serum $250 H D<50 \mathrm{nmol} / \mathrm{l}$ & & & & & & & 0.001 \\
\hline Menף & 30 & $62 \cdot 5$ & 15 & $50 \cdot 0$ & 15 & 83.3 & \\
\hline Women & 38 & 77.6 & 23 & 67.6 & 15 & 100 & \\
\hline & & & & & & & $<0.001$ \\
\hline Spring ${ }^{\star \star}$ & 71 & 78.9 & 39 & 68.4 & 32 & $97 \cdot 0$ & \\
\hline Summer & 57 & $62 \cdot 0$ & 35 & 57.4 & 22 & $71 \cdot 0$ & \\
\hline Autumn & 44 & $53 \cdot 7$ & 26 & $48 \cdot 1$ & 18 & $64 \cdot 3$ & \\
\hline Winter & 59 & $72 \cdot 0$ & 31 & 58.5 & 28 & $96 \cdot 6$ & \\
\hline
\end{tabular}

25OHD, 25-hydroxy vitamin D.

${ }^{*} \chi^{2}$ test for difference between Inuit and non-Inuit participants. † Information missing in nine participants.

$\ddagger$ Information missing in two participants.

§Information missing in three participants.

II Information missing in eight participants.

ๆ Average of four seasonal measurements. None was below $20 \mathrm{nmol} / \mathrm{l}$

${ }^{\star *} P=0.003$ for difference between seasons in all participants.

intake were reported by Inuit participants in town $(P=0 \cdot 10)$ or by Inuit participants in settlement $(P=0.79)$, while non-Inuit participants reported differences $(P<0 \cdot 001)$.

Fig. 3 illustrates the difference between the four seasons in terms of number of hours spent outdoors during each season (Inuit, $P<0.001$; non-Inuit, $P=0 \cdot 012$ ). This difference preceded a parallel variation in serum $250 H D$ concentrations (Fig. 3, $P<0 \cdot 001$ ).

Table 3 lists factors important to serum levels of 25OHD. Season remained important to serum 25OHD concentrations after adjustment for diet, origin, residence, sex, age, vitamin intake and weight. Also, diet, ethnic origin, residence and sex were important to serum levels of $25 \mathrm{OHD}$ in the adjusted analysis (Table 3).

\section{Discussion}

We performed repeated seasonal sampling over 1 year in populations living about $70^{\circ} \mathrm{N}, 400$ to $500 \mathrm{~km}$ north of the Arctic Circle, with marked changes in sunlight due to having over 1 month of polar night and 1 month of midnight sun. We found differences in serum 25OHD concentrations and in the frequency of intake of local marine foods rich in vitamin D. Interestingly, serum 25OHD concentration was influenced 
Table 2. Serum 25-hydroxy vitamin D (25OHD) (nmol/l) concentration as average of seasons and the median with 25 th and 75 th percentiles for each season among inhabitants of the town llulissat and the settlement Saqqaq in North Greenland, and the difference and ratio between autumn and spring ${ }^{*}$

(Median values and 25th-75th percentiles)

\begin{tabular}{|c|c|c|c|c|c|c|c|c|c|c|c|c|c|c|c|}
\hline & \multicolumn{10}{|c|}{ Serum 25OHD } & \multirow[b]{3}{*}{$P \dagger$} & \multirow{2}{*}{\multicolumn{2}{|c|}{$\begin{array}{c}\text { Difference autumn/ } \\
\text { springt }\end{array}$}} & \multirow{2}{*}{\multicolumn{2}{|c|}{$\begin{array}{l}\text { Ratio of autumn: } \\
\text { springt }\end{array}$}} \\
\hline & \multicolumn{2}{|c|}{ Year } & \multicolumn{2}{|c|}{ Spring } & \multicolumn{2}{|c|}{ Summer } & \multicolumn{2}{|c|}{ Autumn } & \multicolumn{2}{|c|}{ Winter } & & & & & \\
\hline & Median & $\begin{array}{l}\text { 25th-75th } \\
\text { percentile }\end{array}$ & Median & $\begin{array}{l}\text { 25th-75th } \\
\text { percentile }\end{array}$ & Median & $\begin{array}{l}\text { 25th-75th } \\
\text { percentile }\end{array}$ & Median & $\begin{array}{l}25 \text { th }-75 \text { th } \\
\text { percentile }\end{array}$ & Median & $\begin{array}{l}\text { 25th-75th } \\
\text { percentile }\end{array}$ & & Median & $\begin{array}{l}25 \text { th }-75 \text { th } \\
\text { percentile }\end{array}$ & Median & $\begin{array}{l}\text { 25th-75th } \\
\text { percentile }\end{array}$ \\
\hline $\begin{array}{l}\text { All partici- } \\
\text { pants }\end{array}$ & $44 \cdot 0$ & $34 \cdot 5-51 \cdot 1$ & $35 \cdot 0$ & $27 \cdot 0-42 \cdot 3$ & $43 \cdot 4$ & $37 \cdot 3-57 \cdot 9$ & $47 \cdot 0$ & $37 \cdot 2-55.0$ & 39.5 & $32 \cdot 2-51 \cdot 1$ & $<0.001$ & $8 \cdot 1$ & $2 \cdot 4-18.7$ & 1.28 & $1.07-1.52$ \\
\hline Men & $45 \cdot 4$ & $36 \cdot 3-55 \cdot 5 \ddagger$ & $36 \cdot 4$ & $30 \cdot 7-46 \cdot 5$ & 47.4 & $39.6-57.9$ & 47.5 & $41.6-57.5$ & $40 \cdot 1$ & $36 \cdot 3-62 \cdot 3$ & $<0.001$ & $8 \cdot 0$ & $2 \cdot 5-20 \cdot 1$ & $1 \cdot 25$ & $1.08-1.56$ \\
\hline Women & 39.0 & $31.9-45.5$ & $32 \cdot 8$ & $26 \cdot 6-40 \cdot 3$ & $41 \cdot 4$ & $36 \cdot 7-51 \cdot 4$ & $46 \cdot 7$ & $33 \cdot 0-52 \cdot 7$ & 35.9 & $30 \cdot 3-43 \cdot 4$ & $<0.001$ & $10 \cdot 1$ & $2 \cdot 2-17 \cdot 8$ & 1.22 & $1.06-1.47$ \\
\hline Non-Inuit & 39.0 & $33 \cdot 2-45 \cdot 0 \ddagger$ & $30 \cdot 3$ & $25 \cdot 4-36 \cdot 6$ & $43 \cdot 2$ & $39 \cdot 3-54.0$ & 43.6 & $35 \cdot 1-51 \cdot 8$ & 32.8 & $26.8-39 \cdot 7$ & $<0.001$ & $12 \cdot 8$ & $6.2-18.5$ & 1.41 & $1 \cdot 20-1 \cdot 68$ \\
\hline Inuit & $44 \cdot 6$ & $35 \cdot 4-58 \cdot 2$ & $36 \cdot 8$ & $28.6-52.7$ & $44 \cdot 7$ & $36.4-59.4$ & 48.6 & $37 \cdot 3-56 \cdot 4$ & 43.5 & $34.3-61.5$ & $<0.001$ & $5 \cdot 8$ & $-2.5-19.1$ & $1 \cdot 14$ & $0.95-1.45$ \\
\hline Town & $46 \cdot 8$ & $36 \cdot 9-60 \cdot 0$ & $42 \cdot 2$ & $31.8-52.9$ & 47.9 & $36 \cdot 8-66 \cdot 1$ & $52 \cdot 6$ & $38.1-62.9$ & 43.8 & $34 \cdot 2-62 \cdot 8$ & $<0.001$ & 9.7 & $2 \cdot 6-20 \cdot 6$ & 1.25 & $1.08-1.45$ \\
\hline Settlement & $42 \cdot 2$ & $34.3-55.6$ & $35 \cdot 0$ & $26 \cdot 9-48 \cdot 3$ & $41 \cdot 3$ & $30 \cdot 5-54.1$ & 43.6 & $30.7-57.4$ & 47.5 & $39.8-69.6$ & $<0.001$ & 1.4 & $-6 \cdot 5-32 \cdot 2$ & 1.03 & $0.82-1.87$ \\
\hline \multicolumn{16}{|l|}{ Age (years) } \\
\hline $30-39$ & 38.4 & $32 \cdot 4-46 \cdot 0 \ddagger$ & 33.7 & $26.9-41 \cdot 7$ & $43 \cdot 2$ & $36 \cdot 0-54 \cdot 8$ & $43 \cdot 2$ & $32.5-51.0$ & $34 \cdot 2$ & $29 \cdot 0-43 \cdot 7$ & $<0.001$ & 6.0 & $-0.9-14.8$ & $1 \cdot 16$ & $0.98-1.51$ \\
\hline $40-49$ & 44.9 & $36.6-54.7$ & 35.9 & $29 \cdot 5-45 \cdot 0$ & $46 \cdot 7$ & $38.7-59.7$ & $50 \cdot 0$ & $40 \cdot 9-63 \cdot 1$ & $42 \cdot 3$ & $37.0-59.2$ & $<0.001$ & 14.9 & $5.5-31.5$ & 1.37 & $1 \cdot 13-1 \cdot 58$ \\
\hline \multicolumn{16}{|c|}{ Main meal Greenlandic (d/week) } \\
\hline $0-1$ & 39.0 & $33 \cdot 4-42 \cdot 4 \ddagger$ & 31.1 & $24 \cdot 3-35 \cdot 4$ & $43 \cdot 2$ & $37.4-52.9$ & $43 \cdot 1$ & $35 \cdot 8-50 \cdot 6$ & 32.9 & $26 \cdot 7-40 \cdot 1$ & $<0.001$ & 14.6 & $4.9-20 \cdot 9$ & 1.49 & $1 \cdot 13-1 \cdot 73$ \\
\hline $2-3$ & $40 \cdot 7$ & $33 \cdot 6-50 \cdot 2$ & $36 \cdot 7$ & $28 \cdot 8-42 \cdot 3$ & $41 \cdot 6$ & $37.4-55.3$ & $47 \cdot 1$ & $35 \cdot 3-55 \cdot 4$ & 39.5 & $33 \cdot 2-44 \cdot 7$ & $<0.001$ & $7 \cdot 0$ & $3.5-15.4$ & 1.21 & $1 \cdot 10-1 \cdot 41$ \\
\hline $4-7$ & $48 \cdot 0$ & $36 \cdot 6-59 \cdot 7$ & $42 \cdot 2$ & $29.8-53.5$ & $50 \cdot 1$ & $33 \cdot 9-65 \cdot 1$ & 48.6 & $41.5-69.4$ & 49.9 & $40.0-75.5$ & $<0.001$ & 5.8 & $-5.5-32.2$ & $1 \cdot 14$ & $0.90-1.75$ \\
\hline
\end{tabular}

* This table includes data from the sixty-three participants not taking vitamin $D$ supplements, who participated at all four seasons.

$\dagger$ Friedman's test for differences between seasons.

$\ddagger P<0.05$. 


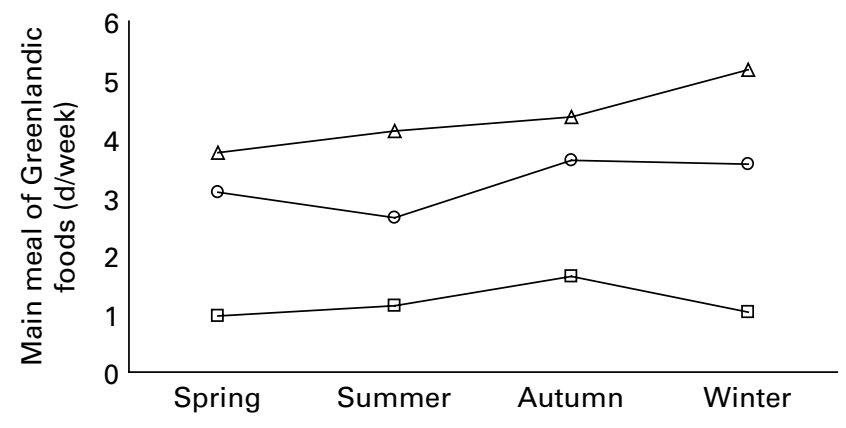

Fig. 2. The reported number of days that the main meal consisted of local Inuit foods for Inuit participants in the settlement $(\triangle)$, Inuit participants in the town ( $\bullet$ ) and non-Inuit ( $\square$ ) participants in each of the four seasons.

by season and residence beyond the effect of diet, sex, ethnicity and vitamin intake.

Vitamin D is acquired through diet and skin exposure to UVB light. Dermal production is determined by length of exposure, latitude, season, degree of skin pigmentation and use of protective clothing ${ }^{(5,10,11)}$.

UVB exposure is absent above the Arctic Circle during the polar night. Also, a high solar zenith angle limits the intensity of light during summer ${ }^{(5,10,11)}$. However, spring in North Greenland is characterised by immense sunlight due to a relatively high influx of sunlight because of low humidity of the air, reflections from snow and ice and the fact that this is a high-pressure area during spring with a long line of sunny days $^{(12)}$. Thus, sunny weather with reflections of light could compensate for the effect of high latitude.

Early Arctic visitors described eye protectors made from sealskin used during spring and summer by the Inuit population $^{(13)}$. This matches later findings of frequent cataract among Greenland Inuit ${ }^{(14,15)}$, as UVB exposure increases the risk of cataract ${ }^{(16,17)}$. Also, dermal synthesis of $25 \mathrm{OHD}$ should be possible in snow-covered terrain at $70^{\circ} \mathrm{N}$ according to Webb \& Engelsen ${ }^{(18)}$. They estimated that it was possible to obtain the UV dose for adequate vitamin D synthesis in human skin at $70^{\circ} \mathrm{N}$ from mid-March through to late September with snow-covered ground, but emphasised that this was highly variable depending on cloudiness, ozone, surface reflection and aerosols ${ }^{(18)}$. Their estimate was based on a theoretical

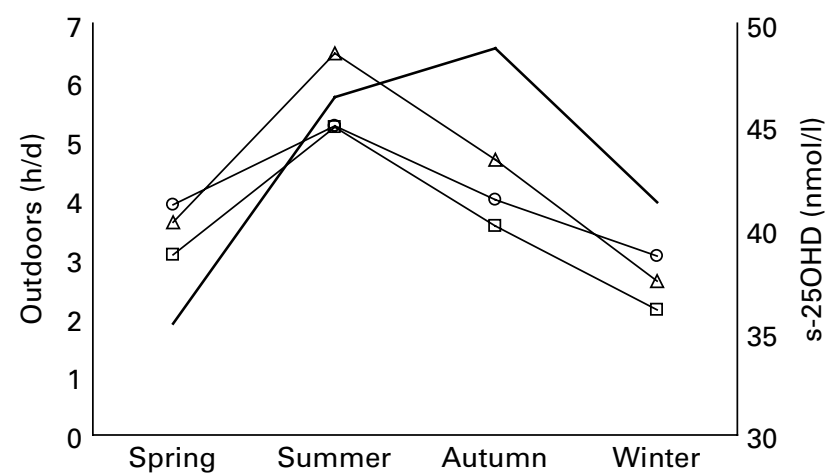

Fig. 3. The average reported number of hours spent outdoors during each of the four seasons for the three participant groups (ordinate to the left). Vitamin $\mathrm{D}$ (serum 25-hydroxy vitamin $\mathrm{D}$; s-25OHD) is superimposed (ordinate to the right). $\triangle$, Inuit settlement; $\bigcirc$, Inuit town; $\square$, non-Inuit; $\longrightarrow$, s-25OHD.
Table 3. Factors important to serum 25-hydroxy vitamin D (25OHD) levels among inhabitants in the town of llulissat and the settlement of Saqqaq at $70^{\circ} \mathrm{N}$ in North Greenland

(Odds ratios and $95 \%$ confidence intervals)

\begin{tabular}{|c|c|c|c|c|c|}
\hline & \multicolumn{2}{|c|}{ Univariate } & \multicolumn{3}{|c|}{ Multivariate } \\
\hline & $P$ mean & $P$ variance $\ddagger$ & $P$ & OR & $95 \% \mathrm{Cl}$ \\
\hline Diet§ & $<0.001$ & $<0.01$ & $<0.001$ & 3.9 & $2 \cdot 0,7 \cdot 8$ \\
\hline Season\| & 0.003 & NSף & $<0.001$ & $2 \cdot 6$ & $1 \cdot 6,4 \cdot 3$ \\
\hline Origin** & 0.001 & $<0.01$ & 0.001 & 2.9 & $1.5,5.5$ \\
\hline Residence†† & NSף & NSף & 0.013 & $2 \cdot 4$ & $1 \cdot 2,4 \cdot 9$ \\
\hline Sexł‡ & NSף & 0.01 & 0.026 & 1.8 & $1 \cdot 1,2 \cdot 9$ \\
\hline Age§§ & 0.016 & $<0.01$ & NSף & 1.5 & $0 \cdot 9,2 \cdot 6$ \\
\hline Vitamin||\| & NS & $<0.01$ & NSף & 1.0 & $0.5,1.9$ \\
\hline Weight ๆ & NSף & NSף & NSף & $2 \cdot 0$ & $0.5,7.4$ \\
\hline
\end{tabular}

* Logistic regression analysis with serum $25 \mathrm{OHD}>50 \mathrm{nmol} / \mathrm{l}$ as the dependent variable. Explanatory variables: origin, residence, sex, age, vitamin intake, diet and weight.

$\dagger \chi^{2}$ test for serum $250 \mathrm{HD}<50 \mathrm{nmol} / \mathrm{l}$.

$\ddagger$ Bartlett's test for homogeneity of variances.

$\S$ Inuit meal $<4$ times/week reference.

\|S Season was included with summer-autumn $v$. winter-spring (reference)

If $P>0.05$

** Non-Inuit reference.

†† Settlement reference.

防omen reference.

§ Age 30-39 years reference.

||| Not daily intake reference.

ๆ $<80 \mathrm{~kg}$ reference.

model, but was supported by others ${ }^{(19)}$. Also, the Danish Meteorological Office reports a UV index of 1 by 1 April and 3 by 21 June in North Greenland ${ }^{(20)}$. These UV index levels are sufficient for dermal 25OHD production and may be even higher with the thinning of the ozone layer ${ }^{(20)}$. Thus, there are indicators of marked UVB exposure in Greenland that support the notion of possible dermal 25OHD production $500 \mathrm{~km}$ north of the Arctic Circle.

Protective clothing is necessary in Ilulissat during spring, where the average ambient temperature rises from $-20^{\circ} \mathrm{C}$ in March to $-0.5^{\circ} \mathrm{C}$ in May and reaches a maximum of $7.5^{\circ} \mathrm{C}$ in July $^{(12)}$. Still, Inuit hunters reported spending up to $16 \mathrm{~h}$ in outdoor activity during spring and summer, and some sun exposure was evident from their marked facial sun tan. Also, arms of hunters may be exposed to the sun during working hours in spring and summer.

The local Inuit diet was important for serum 25OHD production in Inuit and non-Inuit population in the capital Nuuk in West Greenland and in rural Ammassalik district in East Greenland $^{(21)}$. These data were collected by the same investigators (S. A., P. L.), who used the same FFQ and calculated Inuit food frequency scores using the same mathematics as this survey. However, participants in the present survey were 20 years younger and the contribution by local foods was clearly lower than in the East Greenland Inuit diet ${ }^{(21)}$. Still, the expected effect of Inuit diet on serum 25OHD levels was found, and the levels of serum 25OHD were as predicted from the Inuit food frequency scores ${ }^{(21)}$. Thus, we found that serum $25 \mathrm{OHD}$ levels almost doubled from the group with the lowest to the highest quintile of Inuit food frequency scores. A rough estimate based on the present data suggests an increase in serum 25OHD levels of about $4 \mathrm{nmol} / 1$ for each additional day with the main meal of traditional Inuit foods. This influence of marine diet 
on serum 25OHD concentration is in accordance with findings in other north Atlantic populations ${ }^{(22)}$

The seasonal variation in serum 25OHD levels is in keeping with the findings in a previous study of Inuit and non-Inuit subjects in Denmark and south of the Arctic Circle in Greenland $^{(23)}$. They found seasonal differences in diet and in vitamin D concentrations. However, a rather crude dietary classification was used and data on exposure to ambient environment are lacking ${ }^{(23)}$.

Serum 25OHD levels rose markedly during spring and summer, and declined in autumn and winter. Thus, we found a markedly higher risk of serum 25OHD levels below $50 \mathrm{nmol} / 1$ in the samples collected during and following the polar night compared with samples collected during midsummer and autumn. This was consistent after adjusting for diet, intake of vitamin D-containing supplements, age, sex and ethnicity. The seasonal difference may be explained by dermal production of $25 \mathrm{OHD}$, which is consistent with a lower level in Inuit populations in the settlement $100 \mathrm{~km}$ north of Ilulissat. It also fits with the exposure to immense light during spring in North Greenland.

Seasonal differences in serum 25OHD concentrations declined with higher intakes of Inuit foods. Still, a marked seasonal difference in the group with the highest intake of local foods supports the notion that dietary variations do not contribute the full explanation. Moreover, a sex difference in serum $25 \mathrm{OHD}$ levels was seen in Inuit participants only. This is coherent with an effect of exposure to sunlight, as Inuit men are hunters ${ }^{(24)}$ and thus spend markedly more time outdoors than Inuit women. In fact, one in four Inuit men reported spending $8 \mathrm{~h}$ or more outdoors even during winter.

We did not measure dermal 25OHD production. Still, both the adjusted analyses, the serum 25OHD indexed for diet, the sex difference in Inuit participants only, the association with sunlight exposure at the four seasons, the consistent influence of residence and the presence of other indicators of UVB exposure in North Greenland support a possible dermal 25OHD production. A way to detect the contribution from the diet is by measuring vitamin $\mathrm{D}_{2}$ and $\mathrm{D}_{3}$. However, the Inuit diet consists mainly of marine mammals ${ }^{(7)}$ with high contents of $\mathrm{D}_{3}$ that contributed by far to the majority of $25 \mathrm{OHD}$ concentration in Inuit participants ${ }^{(21)}$.

Inuit participants had a higher serum 25OHD concentration than non-Inuit participants. They also had a higher intake of Inuit foods and spent more time outdoors than non-Inuit participants. Still, the ethnic difference was confirmed in the adjusted analysis. This extends our previous finding of an influence of ethnicity on serum $25 \mathrm{OHD}$ concentrations ${ }^{(21)}$. It may be speculated that this relates to an ethnic difference in the absorption or metabolism of vitamin D.

Serum 25OHD level was measured using a RIA assay. Liquid chromatography tandem MS is considered to be the reference method and was used in another study in Greenland ${ }^{(21,25)}$. Still, the findings here were supported by the fact that serum 25OHD levels were in keeping with the levels predicted from Inuit food frequency scores in a previous study ${ }^{(21)}$. Furthermore, the levels in the present study were used for comparison across season and groups, but not for external comparisons.
In conclusion, Inuit population in North Greenland spend up to $16 \mathrm{~h}$ outdoors in spring and summer and are exposed to immense light due to reflections from snow, ice and sea. The present data suggest a contribution to serum 25OHD levels beyond that of the traditional Inuit diet and vitamin D-containing supplements. This may be speculated to be caused by a dermal production of $25 \mathrm{OHD}$ during spring and summer as far north as $70^{\circ} \mathrm{N}$ in addition to the dietary sources of vitamin D.

\section{Acknowledgements}

The authors declare no conflict of interest. The present study was supported by grants from the Greenland Home Government and Karen Elise Jensen Foundation. S. A. conceived the idea, designed the study, raised the funds, collected, analysed and interpreted the data and wrote the manuscript; A. J. analysed and interpreted the data and reviewed the manuscript; P. L. conceived the idea, designed the study, raised the funds, collected and interpreted the data and reviewed the manuscript.

\section{References}

1. Mosekilde L (2005) Vitamin D and the elderly. Clin Endocrinol 62, 265-281.

2. Bischoff-Ferrari HA, Dawson-Hughes B, Willett WC, et al. (2004) Effect of vitamin D on falls: a meta-analysis. JAMA 291, 1999-2006.

3. Bischoff-Ferrari HA, Willett WC, Wong JB, et al. (2009) Prevention of nonvertebral fractures with oral vitamin $\mathrm{D}$ and dose dependency: a meta-analysis of randomized controlled trials. Arch Intern Med 169, 551-561.

4. Adams JS \& Hewison M (2010) Update in vitamin D. J Clin Endocrinol Metab 95, 471-478.

5. Sharma S, Barr AB, Macdonald HM, et al. (2011) Vitamin D deficiency and disease risk among aboriginal Arctic populations. Nutr Rev 69, 468-478.

6. Kuhlein HV, Receveur O, Soueida R, et al. (2007) Unique patterns of dietary adequacy in three cultures of Canadian Arctic indigenous peoples. Publ Health Nutr 11, 349-360.

7. Andersen S, Hvingel B, Kleinschmidt K, et al. (2005) Changes in iodine excretion in 50-69-y-old denizens of an Arctic society in transition and iodine excretion as a biomarker of the frequency of consumption of traditional Inuit foods. Am J Clin Nutr 81, 656-663.

8. Bjerregaard P \& Young TK (1998) The Circumpolar Inuit Health of a Population in Transition. Copenhagen: Munksgaard.

9. Andersen S, Boeskov E \& Laurberg P (2005) Ethnic differences in bone mineral density between Inuit and Caucasians in North Greenland are caused by differences in body size. J Clin Densitom 4, 409-414.

10. Dawson-Hughes B (2004) Racial/ethnic considerations in making recommendations for vitamin D for adult and elderly men and women. Am J Clin Nutr 80, 1963S-1966S.

11. Webb AR, Kline L \& Holick MF (1988) Influence of season and latitude on the cutaneous synthesis of vitamin $\mathrm{D}_{3}$ : exposure to winter sunlight in Boston and Edmonton will not promote vitamin $\mathrm{D}_{3}$ synthesis in human skin. $J$ Clin Endocrinol Metab 67, 373-378.

12. Danmarks Meteorologiske Institut (2012) Weather archives for Greenland. http://www.dmi.dk/dmi/index/gronland/ klimanormaler-gl.htm (accessed 1 March 2012). 
13. M'Keevor T (1819) A Voyage to Hudson's Bay during the Summer of 1812. London: Phillips.

14. Klauber A (1981) Frequency of cataract extraction in Greenlanders. Acta Ophthalmol 59, 532-538.

15. Alsbirk PH, Clemmesen V, Kessing SV, et al. (1989) Eye care in Greenland in 1979-1988. Ugeskr Laeger 151, 3056-3059.

16. Dolin JP (1994) Ultraviolet radiation and cataract: a review of the epidemiological evidence. Br J Ophthalmol 78, 478-482.

17. Delcourt C, Carriere L, Ponton-Sanchez A, et al. (2000) Light exposure and the risk of cortical, nuclear, and posterior subcapsular cataracts: the Pathologies Oculaires Liées à l'Age (POLA) study. Arch Ophthalmol 118, 385-392.

18. Webb AR \& Engelsen O (2006) Calculated ultraviolet exposure levels for a healthy vitamin D status. Photochem Photobiol 82, 1697-1703.

19. Holick MF (2004) Vitamin D: importance in the prevention of cancers, type 1 diabetes, heart disease and osteoporosis. Am J Clin Nutr 79, 362-371.

20. Christensen T, Jønch-Sørensen H, Eriksen P, et al. (2007) UV-radiation in Greenland (UV-stråling i Grønland). Danish Meteorological Institute Scientific Report 07-05.
21. Andersen S, Laurberg P, Hvingel B, et al. (2012) Vitamin D status in Greenland is influenced by diet and ethnicity: a population-based survey in an Arctic society in transition. Br J Nutr (Epublication ahead of print version 8 June 2012).

22. Dalgård C, Petersen MS, Schmedes AV, et al. (2010) High latitude and marine diet: vitamin D status in elderly Faroese. Br J Nutr 104, 914-918.

23. Rejnmark L, Jørgensen ME, Pedersen MB, et al. (2004) Vitamin D insufficiency in Greenlanders on a westernized fare: ethnic differences in calcitropic hormones between Greenlanders and Danes. Calcif Tissue Int 74, 255-263.

24. Andersen S, Kleinschmidt K, Hvingel B, et al. (2012) Thyroid hyperactivity with high thyroglobulin in serum despite sufficient iodine intake in chronic cold adaptation in an Arctic Inuit hunter population. Eur J Endocrinol 166 $433-440$

25. Højskov CS, Heickendorff L \& Møller HJ (2010) Highthroughput liquid-liquid extraction and LCMSMS assay for determination of circulation $25(\mathrm{OH})$ vitamin $\mathrm{D}_{3}$ and $\mathrm{D}_{2}$ in the routine clinical laboratory. Clin Chim Acta 411, $114-116$ 